\title{
MODEL PEMBELAJARAN COOPERATIF INTEGRATED READING COMPOSITION BERPOLA LESSON STUDY MENINGKATKAN KETERAMPILAN MEMBACA DAN MENULIS
}

\author{
Ni Ketut Desia Tristiantari ${ }^{1}$, I Made Sumantri ${ }^{2}$ \\ 1,2 Jurusan Pendidikan Guru Sekolah Dasar, \\ Universitas Pendidikan Ganesha, Indonesia \\ E-mail: desiatristiantari@gmail.com
}

\begin{abstract}
Abstrak
Penelitian ini bertujuan untuk meningkatkan keterampilan membaca dan menulis siswa kelas IV SD N 3 Kampung Anyar dengan menerapkan model pembelajaran CIRC dengan pola lesson study. Penelitian ini menggunakan rancangan penelitian tindakan kelas (PTK) yang dilakukan secara bertahap dengan 2 siklus. Setiap siklus terdiri atas refleksi awal, dilanjutkan dengan rencana tindakan, pelaksanaan tindakan, observasi/evaluasi, dan refleksi. Penelitian ini dilaksanakan pada semester ganjil tahun pelajaran 2016/2017 selama delapan bulan dari bulan April hingga bulan November 2016. Subjek penelitian ini adalah siswa kelas IV SD N 3 Kampung Anyar sebanyak 14 orang. Data keterampilan membaca dan menulis siswa diperoleh dengan menggunakan tes keterampilan berbahasa. Hasil dari penelitian ini adalah ((1) rata-rata keterampilan membaca siswa yang pada siklus I sebesar 67, pada siklus II peningkat mencapai 76 , (2) rata-rata keterampilan menulis siswa yang pada siklus I sebesar 69, pada siklus II peningkat mencapai 79, (3) pada siklus 1 skor keterampilan membaca siswa dengan kategori "baik" dan "sangat baik" hanya mencapai 57,1 $\%$, pada siklus II meningkat menjadi 92,9\%, (4) pada siklus I, keterampilan menulis siswa dengan kategori "baik" dan "sangat baik" hanya 64,3\%, pada siklus II meningkat secara signifikan mencapai 92,9\%. Berdasarkan temuan-temuan tersebut, dapat disimpulkan bahwa penerapan Pembelajaran $\mathrm{CIRC}$ dengan pola lesson study mampu meningkatkan keterampilan membaca dan menulis siswa kelas IV SD N 3 Kampung Anyar Tahun Pelajaran 2016/2017
\end{abstract}

Kata Kunci: $\quad$ CIRC, lesson study, membaca, menulis

\begin{abstract}
This research aims to improve reading and writing skills fourth grade students on Kampung Anyar Elementary School in applying Cooperatif Integrated Reading Composition (CIRC) learning and teaching model with Lesson Study. This research used classroom action research that consist multicycle. Each cycle started plan of action, followed by action, observation and evaluation, and than reflection. This research implemented during eight months, from April until November 2016. Subject of this research is 14 people's fourth grade students. Reading and writing skills data of students obtained using tests of language skills. The result shows that (1) the average reading skills of students in the first cycle is 67 , the second cycle enhancement reached 76 , (2) the average writing skills of students in the first cycle is 69 , the second increased to $79,(3)$ in first cycle, reading skills score of students with the category "good" and "excellent" only $57.1 \%$, in the second cycle increased to $92.9 \%$, and (4) in the first cycle, students writing skills with category "good" and "excellent" only $64.3 \%$, the second cycle increased significantly reaching $92.9 \%$. Based on these result, it can be concluded that CIRC Learning and teaching model with Lesson Study can improve reading and writing skills fourth grade students on Kampung Anyar Elementary School.
\end{abstract}

Keywords: CIRC, Lesson Studi, Reading, Writing 


\section{PENDAHULUAN}

Pendidikan adalah usaha yang dilakukan dengan sengaja dan bertujuan untuk meningkatkan pengetahuan, keterampilan, serta sikap anak didik. Pendidikan memiliki peranan yang sangat penting dalam mewujudkan insan yang cerdas, kompetitif, dan kreatif. Cerdas dapat dimaknai sebagai upaya memanfaatkan akal dan pikiran dalam mengerjakan sesuatu dan menghadapi permasalahan. Kompetitif dapat diartikan sebagai upaya persaingan sehat agar mencapai prestasi di bidang tertentu. Sedangkan kreatif adalah salah satu ciri dari upaya untuk memperoleh sesuatu yang lebih baik dari kondisi sebelumnya.

Salah satu pendidikan formal di sekolah dasar adalah pembelajaran bahasa. Pembelajaran bahasa menjadi sangat penting karena fungsi bahasa yang merupakan alat komunikasi yang bersifat universal. Pembelajaran Bahasa Indonesia merupakan pembelajaran yang kompleks dengan mengutamakan aspek keterampilan berbahasa, yaitu keterampilan menyimak, keterampilan berbicara, keterampilan membaca dan keterampilan menulis (Tarigan, 1987).

Semua aspek tersebut saling barkaitan satu sama lainnya. Manusia sebagai makhluk sosial tidak dapat terlepas dari keempat keterampilan berbahasa tersebut. Begitu pula dengan siswa yang pada hakikatnya adalah makhluk sosial dalam lingkungannya. Penggunaan terhadap aspek keterampilan berbahasa sangatlah diperlukan agar komunikasi berjalan dengan baik dan lancer sehingga pembelajaran bahasa dapat berjalan dengan baik. Pentingnya keterampilan berbahasa tersebut tertuang dalam silabus mata pelajaran Bahasa Indonesia yang disebutkan bahwa Standar Kompetensi Mata Pelajaran Bahasa Indonesia merupakan kualifikasi kemampuan minimal peserta didik yang menggambarkan penguasaan pengetahuan, keterampilan berbahasa, dan sikap positif terhadap bahasa dan sastra Indonesia. Standar kompetensi ini merupakan dasar bagi peserta didik untuk memahami dan merespon situasi lokal, regional, nasional, dan global (Depdiknas, 2006).
Dalam Pelajaran Bahasa Indonesia, membaca merupakan salah satu sumber pengetahuan dan asas pembentukan diri kearah memperoleh ilmu pengetahuan. Tujuan membaca bagi memahami teks yang dibaca dan kandungan teks memberi makna kepada pembaca (Yahya 2005). Pemahaman bacaan bergantung pada gabungan dari segi pengetahuan bahasa, gaya kognitif, dan pengalaman membaca. Sementara itu, kemahiran menulis merupakan suatu budaya intelek yang saling melengkapi antara kemahiran membaca dengan menulis yang cerdas.

Membaca merupakan suatu kesatuan kegiatan yang terpadu yang mencakup beberapa kegiatan, seperti mengenali huruf dan kata-kata, menghubungkannya dengan bunyi dan maknanya, serta menarik kesimpulan mengenai maksud bacaan (Akhadiah et al. 1991). Membaca didefinisikan sebagai suatu proses yang melibatkan penafsiran kode dan pemahaman (Wilson \& Gambrell 1988). Membaca merupakan satu alat pembelajaran yang efektif karena memberi kekuatan pada seorang murid untuk membuat keputusan yang tepat dalam meningkatkan proses pembelajaran dan pemikiran. Seorang pembaca dapat memahami dan menilai teks yang dibaca dengan mengaktifkan skema prosedur dan isi skema yang terdapat di dalam dirinya. Proses membaca merupakan proses kognitif yang dialami secara individu. Proses kognitif ini penting untuk membantu meningkatkan daya baca (Nambiar 2005; Urquhart \& Weir 1998). Membaca pada hakikatnya adalah proses yang rumit yang melibatkan banyak hal, tidak hanya sekedar melafalkan tulisan, tetapi juga melibatkan aktivitas visual, berpikir, psikolinguistik, dan metakognitif. Sebagai proses visual, membaca merupakan proses menerjemahkan simbol tulisan (huruf) ke dalam kata-kata lisan.

Farida Rahim (2008:1) menjelaskan bahwa proses belajar yang paling efektif dilakukan melalui kegiatan membaca. Tujuan akhir dari membaca adalah memahami isi bacaan, tetapi ke nyataan yang ada belum semua siswa dapat mencapai tujuan tersebut. Banyak anak yang dapat membaca lancar suatu bahan bacaan tetapi tidak memahami isi bahan 
bacaan tersebut. Membaca pemahaman merupakan salah satu aspek kemampuan berbahasa yang harus dikuasi oleh siswa sekolah dasar terutama pada kelas lanjut. Melalui kegiatan ini siswa dapat memperoleh informasi secara aktif reseptif.Disebut reseptif karena dengan membaca, seseorang akan memperoleh informasi, memperoleh ilmu pengetahuan dan pengalaman baru (Darmiyati Zuchdi dan Budiasih, 2001:56).

Henry Guntur Tarigan (2008:7) mengungkapkan bahwa membaca adalah suatu proses yang dilakukan untuk memperoleh pesan, yang hendak disampaikan oleh penulis melalui media kata-kata/bahasa tulis. Hal senada juga dikemukakan oleh Harjasujana (melalui Khuddaru Sadhono, 2012:65) yang menyatakan bahwa membaca merupakan kegiatan merespon lambang-lambang tertulis dengan menggunakan pengertian yang tepat. Samsu Somadayo (2011:4) mengartikan membaca sebagai suatu kegiatan interaktif untuk memetik serta memahami arti atu makna yang terkandung di dalam bahan tulis.

Sebagai suatu proses berpikir, membaca mencakup aktivitas mengenal kata, pemahaman literal, interpretasi, membaca kritis, dan pemahaman kreatif. Pengenalan kata dapat berupa aktivitas membaca kata-kata dengan menggunakan kamus (Crawley \& Mountain 1995). Pearson dan Tierney (1984) menyatakan bahwa kemampuan membaca sebagai proses mental yang aktif melibatkan pengajaran mendapatkan makna teks. Oleh sebab itu, proses memahami teks yang dibaca melibatkan aktivitas-aktivitas kognitif, khususnya yang melibatkan kesadaran metakognitif. Jika dipandang dari segi penguasaan membaca, pada dasarnya hubungan antara penguasaan kemampuan membaca dengan strategi metakognitif yang digunakan mempunyai hubungan. Pandangan ini berdasarkan pada hubungan yang erat antara bahasa dengan pikiran, seperti yang dikemukakan oleh Vygotsky dan Luria (Suhor 1984). Selain itu, Pearson dan Tierney (1984) memandang kemampuan membaca sebagai proses mental yang aktif melibatkan pengajaran untuk mendapatkan makna teks.
Dalam usaha mempertingkat kemahiran bahasa murid-murid ini, guru mempunyai peranan yang besar. Menurut Roselan (2003), kemahiran berbahasa merupakan kemahiran asas yang amat penting dan perlu ditekankan dalam proses pengajaran dan pembelajaran. Murid yang mewarisi tahap

Berdasarkan observasi awal di SD Negeri 3 Kampung Anyar Singaraja, ditemukan beberapa permasalahan yaitu kurangnya minat baca dan menulis siswa. Hal ini terlihat dari kurangnya motivasi siswa mengisi waktu luangnya untuk membaca di perpustakaan sekolah. Di samping itu, temuan di lapangan menunjukkan bahwa pembelajaran di kelas masih berpusat pada guru. Guru lebih banyak menggunakan metode ceramah, sedangkan keterampilan berbahasa seharusnya menuntut siswa yang aktif karena pada hakikatnya keterampilan berbahasa dapat dikuasai melalui latihan-latihan yang intensif bukan hanya melalui pemahaman. Hal ini bermuara pada hasil belajar siswa yang masih jauh dari harapan. Perolehan nilai ulangan harian siswa hanya mencapai nilai 6,05 , sedangkan KKM yang ditetapkan sekolah adalah 7,0.

Temuan ini diperkuat oleh hasil wawancara kepada guru kelas IV yang manyatakan bahwa sulitnya mengondisikan kelas pada pelajaran Bahasa Indonesia. Sebagian besar siswa kesulitan menggunakan bahasa Indonesia karena bahasa Indonesia bukan menjadi bahasa ibu (b1) mereka. Ketika guru mengajak siswa berlatih membaca dan menulis, terdapat beberapa siswa yang mengalami kesulitan sehingga waktu pembelajaran tidak berjalan dengan efisisien. Beberapa siswa lain menganggap pembelajaran Bahasa Indonesia adalah pembelajaran yang menjenuhkan sehingga siswa asik berbincang dan bermain dengan temantemannya. Hal ini sangat mengganggu pembelajaran sehingga pembelajaran Bahasa Indonesia di kelas tidak dapat berjalan dengan efektif.

Berdasarkan observasi awal dan wawancara guru tersebut, maka perlu diupayakan langkah-langkah untuk mengantisipasi sekaligus memperbaiki proses pembelajaran ke arah yang lebih 
baik. Peran guru sangatlah penting dalam melaksanakan kegiatan pembelajaran. Di samping harus menguasai bahan atau materi ajar, para guru harus mengetahui pula cara materi ajar itu disampaikan dan bagaimana pula karakteristik peserta didik yang menerima pelajaran tersebut. Agar pembelajaran di kelas dapat berlangsung efektif, diperlukan model pembelajaran yang dapat mengaktifkan siswa. Salah satunya adalah dengan menerapkan model pembelajaran kooperatif.

Model pembelajaran kooperatif merupakan suatu model pembelajaran yang mengutamakan adanya kelompokkelompok. Setiap siswa yang ada dalam kelompok mempunyai tingkat kemampuan yang berbeda-beda (Slavin, 2008). Model pembelajaran kooperatif mengutamakan kerja sama dalam menyelesaikan permasalahan untuk menerapkan pengetahuan dan keterampilan dalam rangka mencapai tujuan pembelajaran (Trianto, 2010). Proses pembelajaran dengan model pembelajaran kooperatif mendorong siswa untuk bekerja sama pada suatu tugas bersama dan mereka harus mengkoordinasikan usahanya untuk menyelesaikan tugas yang diberikan guru. Tujuan model pembelajaran kooperatif adalah hasil belajar akademik siswa meningkat dan siswa dapat menerima berbagai keragaman dari temannya, serta berkembangnya keterampilan sosial.

Salah satu model pembelajaran kooperatif yang dinilai akomodatif dapat meningkatkan keterampilan berbahasa siswa adalah model pembelajaran Cooperatif Inegratif Reading Composition (CIRC). Menurut Nur (2008), CIRC merupakan model pembelajaran kooperatif yang memadukan membaca dan menulis yang disertai dengan kegiatan pemecahan masalah. Model pembelajaran CIRC memiliki delapan komponen : Teams, Placement test, Student creative, Team study, Team scorer and team recognition, Teaching group, Facts test, dan Wholeclass units. Penerapan Model CIRC ini menggunakan pola Lesson Study yang menganut prinsip kolaborasi karena pengamat dan guru selalu bersama-sama dalam melaksanakan pembelajaran. Lesson study merupakan model pembinaan profesi pendidik melalui pengkajian pembelajaran secara kolaboratif dan berkelanjutan berdasarkan prinsip-prinsip kolegalitas dan mutual learning untuk membangun learning community. Kegiatan awal yang dilakukan adalah merencanakan semua kegiatan pembelajaran (Plan), yang dilanjutkan dengan pelaksanan pembelajaran (Do), dan setelah itu dilaksanakan diskusi terhadap hasil pembelajaran $(S e)$. Dengan penerapan Model Pembelajaran CIRC berpola Lesson Study, diharapkan dapat meningkatkan keterampilan membaca dan menulis siswa kelas IV SD N 3 Kampung Anyar, Singaraja.

\section{METODE}

Penelitian ini menggunakan rancangan penelitian tindakan kelas (PTK) yang dilakukan secara bertahap dan multisiklus untuk mendapatkan hasil terbaik agar diperoleh data yang valid. Setiap siklus terdiri atas refleksi awal, dilanjutkan dengan rencana tindakan, pelaksanaan tindakan, observasi/evaluasi, dan refleksi. Tahapan pada masing-masing siklus dilakukan dengan pola Lesson Study. Penelitian ini dilaksanakan SD Negeri 3 Kampung Anyar, Kecamatan Buleleng, Kabupaten Buleleng pada semester ganjil tahun pelajaran 2016/2017 selama kurang lebih delapan bulan dari bulan Mei hingga bulan Oktober. Subjek penelitian ini adalah siswa kelas IV SD Negeri 3 Kampung Anyar yang berjumlah 14 orang dengan objek penelitian adalah keterampilan membaca dan keterampilan menulis siswa.

Data keterampilan membaca dan keterampilan menulis siswa dikumpulkan dengan menggunakan instrumen penilaian yang dirancang peneliti dengan mengacu pada grand teori keterampilan berbahasa dan materi Bahasa Indonesia kelas IV SD. Data dianalisis menggunakan analisis deskriptif kuantitatif dan dilakukan pengambilan keputusan berdasarkan pedoman konversi skala lima seperti pada Tabel 1. 
Tabel 1. Pedoman Konversi Skala Lima Keterampilan Membaca dan Menulis Siswa

\begin{tabular}{|c|c|}
\hline Kriteria & Kategori \\
\hline $85 \leq \bar{X} \leq 100$ & Sangat Baik \\
\hline $70 \leq \bar{X}<85$ & Baik \\
\hline $55 \leq \bar{X}<70$ & Cukup \\
\hline $40 \leq \bar{X}<55$ & Kurang \\
\hline $\bar{X}<40$ & Sangat Kurang \\
\hline
\end{tabular}

\section{HASIL DAN PEMBAHASAN}

Hasil penelitian pada masing-masing siklus mencakup skor keterampilan membaca dan keterampilan menulis siswa setiap siklusnya dapat dilihat pada Tabel 2 . Tabel 2 menunjukkan bahwa pada siklus I terdapat 1 orang atau $7,1 \%$ siswa yang keterampilan membacanya ada pada kategori "sangat baik". Terdapat 7 siswa atau $50 \%$ siswa yang keterampilan membacanya "baik", sedangkan siswa yang keterampilan membacanya "cukup" berjumlah 5 orang atau 35,7\% dan 1 orang siswa atau 7,1 \% berada pada kategori "kurang". Sedangkan pada siklus II terdapat 3 orang atau $21,4 \%$ siswa yang keterampilan membacanya ada pada kategori "sangat baik". Terdapat 10 siswa atau $71,4 \%$ siswa yang keterampilan membacanya "baik", sedangkan siswa yang keterampilan membacanya "cukup" berjumlah 1 orang atau $7,1 \%$.

Tabel 2. Distribusi Skor Keterampilan Membaca Siklus I dan II

\begin{tabular}{|c|c|c|c|c|c|}
\hline \multirow[t]{2}{*}{ Kriteria } & \multicolumn{2}{|c|}{ Keterampilan Membaca } & \multicolumn{2}{|c|}{ Keterampilan Menulis } & \multirow[t]{2}{*}{ Keterangan } \\
\hline & Siklus I & Siklus II & Siklus I & Siklus II & \\
\hline $85 \leq \bar{X}<100$ & 7,1 & 21,4 & 7,1 & 35,7 & Sangat baik \\
\hline $70 \leq \bar{X}<85$ & 50,0 & 71,4 & 57,1 & 57,1 & Baik \\
\hline $55 \leq \bar{X}<70$ & 35,7 & 7,1 & 28,6 & 711 & Cukup \\
\hline $40 \leq \bar{X}<55$ & 7,1 & 0,0 & 7,1 & 0,0 & Kurang \\
\hline $\bar{X}<40$ & 0,0 & 0,0 & 0,0 & 0,0 & Sangat Kurang \\
\hline
\end{tabular}

Pada Tabel 2 juga menunjukkan bahwa pada siklus I terdapat 1 orang atau $7,1 \%$ siswa yang keterampilan menulisnya ada pada kategori "sangat baik". Terdapat 8 siswa atau $57,1 \%$ siswa yang keterampilan menulisnya "baik", sedangkan siswa yang keterampilan menulisnya "cukup" berjumlah 4 orang atau $28,6 \%$ dan 1 orang siswa atau $7,1 \%$ berada pada kategori "kurang". Sedangkan pada siklus II terdapat 5 orang atau 35,7 \% siswa yang keterampilan menulisnya ada pada kategori "sangat baik". Terdapat 8 siswa atau 57,1\% siswa yang keterampilan menulisnya "baik", sedangkan siswa yang keterampilan menulisnya "cukup" berjumlah 1 orang atau $7,1 \%$.
Gambar 1. Peningkatan Rata-rata Keterampilan Membaca dan Menulis

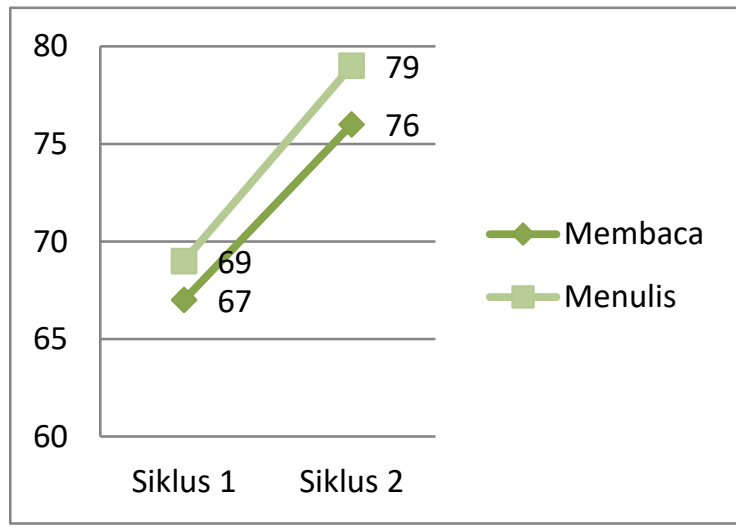


Jika dilihat dari perolehan skor kerapilan membaca siswa yang berada pada kategori "baik" dan "sangat baik" mencapai 92,9\%. Begitu pula skor perolehan keterampilan menulis siswa yang mengalami peningkatan secara signifikan yaitu sebesar 92,9 \% yang mencapai kategori "baik" dan "sangat baik". Jadi hasil penelitian ini menunjukkan bahwa penerapan model pembelajaran CIRC telah mampu meningkatkan ketarampilan membaca dan menulis siswa. Peningkatan rata-rata keterampilan membaca dan menulis siswa dari siklus I ke siklus II dapat dilihat pada Gambar 1.

Berdasarkan analisis data penelitian yang telah diperoleh, terdapat peningkatan skor rata-rata keterampilan membaca siswa pada setiap siklusnya. Pada siklus pertama rata-rata skor keterampilan membaca siswa adalah 67 dengan persetase ketuntasan sebesar $57,1 \%$. Pada siklus II meningkat mencapai rata-rata 76 dengan persentase ketuntasan sebesar 92,2\%. Secara spesifik pada siklus I belum mampu meningkatkan keterampilan membaca dan menulis siswa. Hal ini dilihat dari skor keterampilan membaca siswa dengan kategori "baik" dan "sangat baik" hanya mencapai $57,1 \%$. Keterampilan menulis siswa dengan kategori "baik" dan "sangat baik" juga hanya $64,3 \%$. Hal ini menunjukkan bahwa penelitian ini belum mencapai indikator keberhasilan yang telah ditentukan, sehingga penelitian ini harus dilanjutkan ke siklus berikutnya. Belum optimalnya keterampilan membaca dan menulis siswa pada siklus I disebabkan oleh proses pembelajaran yang masih mengalami beberap kendala, yaitu satu, siswa masih belum terbiasa dengan penerapan model pembelajaran $\mathrm{CIRC}$ sehingga siswa masih menunggu arahan guru yang menyebabkan waktu pembelajaran menjadi kurang efisien; dua, kebiasaan siswa belajar dengan metode ceramah membuat siswa merasa sedikit kesulitan ketika dihimbau untuk mengerjakan LKS dan tiga, kebiasaan siswa bekerja secara individualism menyebabkan pembelajaran kooperatif menjadi kurang efektif, karena masih ada beberapa siswa dalam kelompoknya tidak mau berbagi pendapat.
Kendala awal yang dialami guru dalam pembelajaran yaitu kesulitan mengondisikan kelas pada pembelajaran bahasa Indonesia karena kurangnya penguasaan bahasa Indonesia siswa dan kejenuhan siswa dalam pembelajaran bahasa Indonesia yang dianggap sangat monoton mampu diatasi dengan penerapan model pembelajaran CIRC. Penerapan model CIRC memberi makna yang mendalam di dalam proses pembelajaran sehingga dapat menumbuhkan interaksi yang aktif dan positif antara siswa dengan guru, siswa dengan lingkungannya, maupun antara siswa itu sendiri. Komunikasi antar siswa dapat terjalin dengan baik. Pada penerapan model CIRC ini, siswa belajar secara berkelompok, saling berinteraksi dan saling membantu satu sama lainnya, sehingga siswa yang lemah terbantu oleh siswa yang mampu. Siswa yang telah mampu pun tidak merasa jenuh dengan pembelajaran yang hanya berpusat pada guru. Hasil ini menunjukkan bahwa model pembelajaran CIRC dapat meningkatkan keterampilan membaca pemahaman siswa. Penelitian ini diperkuat dengan hasil penelitian Suci Prima Ayu Megalia pada tahun 2013 dengan judul penelitian "Pembelajaran Matematika dengan Menggunakan Model CIRC untuk Meningkatkan Kemampuan Pemahaman dan Komunikasi Matematis Siswa". Hasil penelitian ini adalah dengan menerapkan Model Pembelajaran CIRC kemampuan pemhaman dan komunikasi matematis siswa dapat ditingkatkan.

Dengan penerapan model pembelajaran CIRC, Skor rata-rata keterampilan menulis siswa pada siklus I sebesar 69 dengan persentase ketuntasan $64 \%$, pada siklus II meningkat mencapai rata-rata 79 dengan persentase ketuntasan $92 \%$. Hal ini menunjukkan adanya peningkatan keterampilan menulis siswa. Diskusi siswa dalam kelompoknya pada tahapan teaching group sangat membantu siswa yang mengalami kesulitan menuangkan gagasannya dalam bentuk tulisan. Dengan mendiskusikan ide-idenya, siswa merasa percaya diri dan tidak merasa cemas lagi dalam menulis. Penerapan model CIRC mampu meningkatkan minat 
siswa dalam menulis sehingga bermuara pada peningkatan hasil belajar siswa.

Penerapan Model Pembelajaran CIRC dengan pola Lesson Study memberikan banyak hal positif dan dianggap efektif dalam mengubah praktik mengajar guru seperti penggunaan materi pembelajaran yang konkrit untuk memfokuskan pada permasalahan agar lebih bermakna, mengambil konteks pembelajaran dan pengalaman guru yang eksplisit, dan juga memberikan dukungan pada guru dalam hubungan sejawat. Dengan kata lain, lesson study memberikan banyak kesempatan kepada para guru untuk membuat bermakna ide-ide pendidikan dalam praktik mengajar mereka, untuk mengubah perspektif mereka tentang pembelajaran, dan untuk belajar mengamati praktik mengajar mereka dari perspektif siswa. Temuan dalam penelitian ini didukung oleh pernyataan yang dikemukakan Cerbin \& Kopp (2006) bahwa praktik lesson study sangat membantu meningkatkan pengetahuan guru maupun kualitas pembelajaran yang dilakukan sesuai bidangnya.

Temuan ini sejalan dengan teori yang dikemukakan oleh Slavin (1995:35) bahwa model pembelajaran CIRC ini memiliki beberapa keunggulan, yakni (1) memberikan pengalaman dan membuat kegiatan belajar anak didik menjadi relevan dengan tingkat perkembangan anak; (2) memberikan kesempatan bagi siswa untuk memilih kegiatan belajar sesuai dengan minat siswa dan kebutuhan anak; (3) membuat kegiatan belajar lebih bermakna bagi anak didik sehingga hasil belajar anak didik akan dapat bertahan lebih lama; (4) merupakan pembelajaran terpadu yang menumbuhkembangkan keterampilan berpikir anak; (5) model pembelajaran CIRC merupakan pembelajaran terpadu menyajikan kegiatan yang bersifat bermanfaat sesuai dengan permasalahan yang ditemui dalam lingkungan anak; (6) merupakan pembelajaran terpadu yang dapat menumbuhkan motivasi belajar siswa kearah belajar yang dinamis, optimal, dan tepat guna; (7) dapat menumbuhkembangkan interaksi sosial anak, seperti kerja sama, toleransi, komunikasi, dan menghargai gagasan orang lain; (8) model pembelajaran CIRC dapat membangkitkan motivasi belajar, memperluas wawasan, dan aspirasi guru dalam mengajar.

Hasil penelitian ini memiliki kesamaan dengan penelitian yang pernah dilaksanakan oleh Made Weda Satwika pada tahun 2012 dengan judul Penerapan Model Pembelajaran Cooperative Integrated Reading and Composition (CIRC) Berbasis Penemuan Dalam Menyelesaikan Soal Cerita Untuk Meningkatkan Hasil Belajar Matematika Siswa Kelas IV Semester Ganjil dI SD Negeri 1 Kalianget. Selain itu, Irawadi (2012) menemukan bahwa penerapan model pembelajaran Cooperative Integrated Reading and Composition (CIRC) dapat meningkatkan hasil belajar menulis karya ilmiah siswa. Hal ini dapat dilihat dalam perbandingan skor rata-rata klasikal, yakni pada pratindakan skor rata-rata klasikal 68,2 (cukup), siklus I memperoleh skor rata-rata klasikal 75,7 (baik), sedangkan pada siklus II nilai rata-rata klasikal siswa menjadi 82,2 (baik). Hasil penelitian ini juga menunjukkan bahwa ada peningkatan aktivitas guru dan aktivitas siswa dalam pembelajaran menulis karya ilmiah dengan menggunakan model pembelajaran Cooperative Integrated Reading and Composition (CIRC). Dari penelitian ini, penelitian sebelumnya terdapat kesamaan dalam pemerolehan hasil, yakni meningkatnya rata-rata nilai pembelajaran. Jadi, penelitian ini menguatkan penelitian-penelitian sebelumnya yang menyatakan bahwa model pembelajaran CIRC masih relevan digunakan untuk meningkatkan hasil belajar siswa.

\section{SIMPULAN DAN SARAN}

Terdapat beberapa temuan pada penelitian ini, yaitu: pertama rata-rata keterampilan membaca siswa yang pada siklus I sebesar 67, pada siklus II peningkat mencapai 76; kedua rata-rata keterampilan menulis siswa yang pada siklus I sebesar 69, pada siklus II peningkat mencapai 79; ketiga, pada siklus 1 skor keterampilan membaca siswa dengan kategori "baik" dan "sangat baik" hanya mencapai $57,1 \%$, pada siklus II meningkat menjadi $92,9 \%$ dan keempat pada siklus I, keterampilan menulis siswa dengan kategori "baik" dan "sangat 
baik" hanya $64,3 \%$, pada siklus II meningkat secara signifikan mencapai 92,9\%. Berdasarkan temuan-temuan yang dipaparkan sebelumnya, dapat disimpulkan bahwa penerapan pembelajaran CIRC mampu meningkatkan keterampilan membaca dan menulis siswa kelas IV SD N 3 Kampung Anyar tahun pelajaran 2016/2017.

\section{DAFTAR PUSTAKA}

Akhadiah M.K., Sabarti, Maidar G. Arsjad, dan Sakura H. Ridwan. (1991). Bahasa Indonesia.Jakarta: Departemen Pendidikan dan Kebudayaan.

Auzar. (2012). Keberkesanan penggunaan perisian asas membaca. GEMA Online Journal of Language Studies, 12(2), 629-644.

Cerbin, W. \& Kopp, B. (2006). Lesson Study as a Model for Building Pedagogical Knowledge and Improving Teaching.

Crawley, S.J. \& Mountain, L. (1995). Strategies for Guiding Content Reading. Boston: Allyn and Bacon.

Darmiyati Zuchdi dan Budiasih (2001). Pendidikan Bahasa dan Sastra Indonesia di Kelas Rendah. Yogyakarta: PAS

Depdiknas, (2006). Kurikulum Tingkat Satuan Pendidikan. Jakarta: Depdiknas.

Farida Rahim. (2008). Pengajaran Membaca di Sekolah Dasar. Jakarta: Bumi Aksara.

Henry Guntur Tarigan. (2008). Membaca: sebagai Suatu Keterampilan Berbahasa. Bandung: Angkasa.

Irawadi, M. H., I Nengah Martha, I Wayan Wendra. (2015). Penerapan Model Pembelajaran Cooperative Integrated Reading And Composition (CIRC) Untuk Meningkatkan Hasil Belajar Siswa Dalam Menulis Karya IImiah Di Kelas Xii Ap I Smk Negeri 1 Seririt. eJournal Universitas Pendidikan Ganesha Jurusan Pendidikan Bahasa dan Sastra Indonesia. Volume 3 No. 1 Tahun 2015.
Megalia, Suci Prima Ayu. (2013). Pembelajaran Matematika dengan Menggunakan Model CIRC untuk Meningkatkan Kemampuan Pemahaman dan Komunikasi Matematis Siswa. Tesis. Bandung: Universitan Pendidikan Indonesia.

Nambiar, R. (2005). Language learning and language use strategies for academic letracy: Towards a theoretical and pedagogical model of language learning. Tesis. Ph.D. Universiti Kebangsaan Malaysia, Bangi.

Nur, Mohamad. (2008). Pengajaran Berpusat Kepada Siswa dan Pendekatan Konstruktivis dalam Pengajaran. Surabaya: Unesa

Pearson, P. D., and R. J. Tierney. (1984). On becoming a thoughtful reader: Learning to read like a writer. In Purves and Niles 1984.

Roselan Baki. (2003). Pengajaran dan pembelajaran penulisan bahasa Melayu. Shah Alam: Karisma Publications Sdn. Bhd.

Samsu Somadayo. (2011). Strategi dan Teknik Pembelajaran Membaca. Yogyakarta: Grahallmu.

Satwika, Made Weda. (2012). Penerapan Model Pembelajaran Cooperative Integrated Reading And Compotition (CIRC) Berbasis Penemuan Dalam Menyelesaikan Soal Cerita Untuk Meningkatkan Hasil Belajar Matematika Siswa Kelas IV Semester Ganjil dl SD Negeri 1 Kalianget. Mimbar PGSD. Vol: 6 No: 1 Tahun: 2012.

Slavin, Robert E. (2008). Cooprative Learning, Teori, Riset, dan Praktik. Bandung: Nusa Media.

Suhor, C. (1984). Report on trends and issues in English: A summary of report from the NCTE Commisions. 10pp. ED 239290.

Tarigan, Henry Guntur. (1990). Menyimak sebagai Suatu Keterampilan Berbahasa. Bandung: Angkasa. 
Trianto. (2010). Mendesain Model Pembelajaran Inovatif- Progesif. Jakarta: Kencana.

Wilson, R.M. \& Gambrell, L.B. (1998). Reading comprehension in the elementary school: A teacher's pratical guide. Newton, MA: Allyn and Bacon.

Yahya Othman. (2005). Trend dalam pengajaran Bahasa Melayu. Bentong: PTS Publications \& Distributors Sdn. Bhd. 